\title{
5. MINERALOGY, GEOCHEMISTRY, AND PETROGRAPHY OF SEDIMENTS RECOVERED AT SITE 345, DSDP LEG 38
}

\author{
A.G. Kossovskaya and V.A. Drits, Geological Institute of the Academy of Sciences, USSR
}

\section{INTRODUCTION}

The mineralogy, geochemistry, and petrography of sediments recovered from Site 345 are discussed. Site 345 was located near the base of the Mohns Ridge near the western margin of the Lofoten Basin. The coring program was designed to penetrate horizontal (turbidite?) layers, which in turn abut against a folded transparent sediment sequence.' ${ }^{1}$ The latter, in turn overlie basement.

\section{LITHOLOGIC DESCRIPTIONS}

Series 1 (Pleistocene to early Miocene; Cores 1-1 to 6-4, Samples 241-246, depth 0-58 m)

The series boundary by the shipboard sedimentologist was established at Core 5-4. According to petrographic data, the boundary should be placed at a lower level. Sediments of Core 6-2 (Sample 246) are a clay graywacke genetically identical to those of Core 5 .

Series 1 consists of very poorly sorted and clayey graywackes and silty sandy clays. The clastic content varies between $10 \%-20 \%$ and $50 \%$. The clastic grains range in size from $0.5-0.6 \mathrm{~mm}$ to $0.02-0.01 \mathrm{~mm}$. Clastic grains consist of irregular, acute-angled quartz, a few quartzite fragments, plagioclase, and less common mica and sparse glauconite grains. Álso present are occasional pyroxene and amphibole fragments, single, short-column zircon grains $(0.02-0.08 \mathrm{~mm})$, as well as foraminifera shells. The clayey matrix is finely interspersed with carbonate (Sample 243).

An interbedding of typical clastic mixed-layer clay material (Samples 241, 243, 244) with more montmorillonitic clays (formed from volcanic glass, Samples 242,245 ) is characteristic. Principal components of the clastic clays are alteration products of biotite, illite, and kaolinite. Diffraction patterns of the samples show (in the small-angle region) a broad "indented" reflection in the $10-14 \AA$ range (Table 1 ). This is evidence of differing degrees of hydration of montmorillonite interlayers. After glycerine saturation, the diffraction patterns record a broad peak from 14 to $19 \AA$, which indicates that the montmorillonite component is virtually a mixed-layer phase of montmorillonite-vermiculite. The transformation of biotite through the vermiculite and

\footnotetext{
'For the purposes of this paper, the sediments have been grouped into "series" (Figure 1). The "series" do not necessarily correspond to "units" as defined by shipboard sedimentologists (see Site Report chapter, this volume). Also sediment terminology is that of the authors and may not correspond to shipboard designations. Sample numbers are those assigned by the authors for the investigations.
}

mixed-layer phases is a widespread process in continental sedimentary rocks. This has been thoroughly investigated and is known to be characterized by diffraction effects similar to those just described (Kossovskaya et al., 1963). The micaceous component does not contain expandable layers and belongs to the illite group. The $\mathrm{Mg}-\mathrm{Fe}$ chlorites often have imperfect brucite layers. Apparently, they are also a product of biotite transformation.

A reticular texture, characteristic in the montmorillonitization of volcanic glass, is typical of montmorillonitic clays. Often present are acute-angled quartz grains, amphiboles, and pyroxenes; the latter illustrate the exsolution "cock's combs." Phillipsite sometimes develops after glass fragments. The montmorillonites containing aluminum have a low iron content and may contain various absorbed cations. Sometimes glycerine saturated samples (Sample 246) have a diffraction pattern characterized by abnormally high values, $d_{(001)}$, of the small-angle reflection $19.8 \AA$. This indicates a weak crystallization, a dispersed character of montmorillonite, or the presence of mixedlayer units.

The base of the series consists of a graywacke with an abundant clay matrix. The composition of the clay matrix is a montmorillonitic mixed-layer clay, with the montmorillonite being poorly crystallized.

\section{Series 2 (late Oligocene or early Miocene; Cores 7-2 to 10-5, Samples 247-255, depth 65-139 m)}

Series 2 nearly conforms to Subunit 2A of the shipboard designation. However, the upper boundary of the series is at the top of Core 7-1, and the lower boundary is at the base of Core 10-5 (Figure 1). This series should be set apart as an independent series inasmuch as the lithologic character (with typical siliceous-clay deposits) is not present elsewhere in the section. The underlying deposits of Series 3 and 4 consist of highly uniform clayey siltstones.

The series consists of siliceous clays, and more rarely clay diatomites, which are green-gray and have a fineaggregate, sometimes reticular, texture. The sediments consist of a high-dispersed clay mass of a predominantly montmorillonitic composition, finely interspersed with siliceous microfossils including diatom fragments, Radiolaria, and occasional sponge spicules. Well-preserved forms are rather rare. Fragments of green-brown, more rarely colorless glasses $(n=1.52$ 1.55) are present. These are sometimes replaced by a fine aggregate of zeolites (phillipsite?). Lower in the sediment section, the admixture of clastic material increases including small quartz grains, rare fragments of fresh plagioclase, mica flakes, and single glauconite 


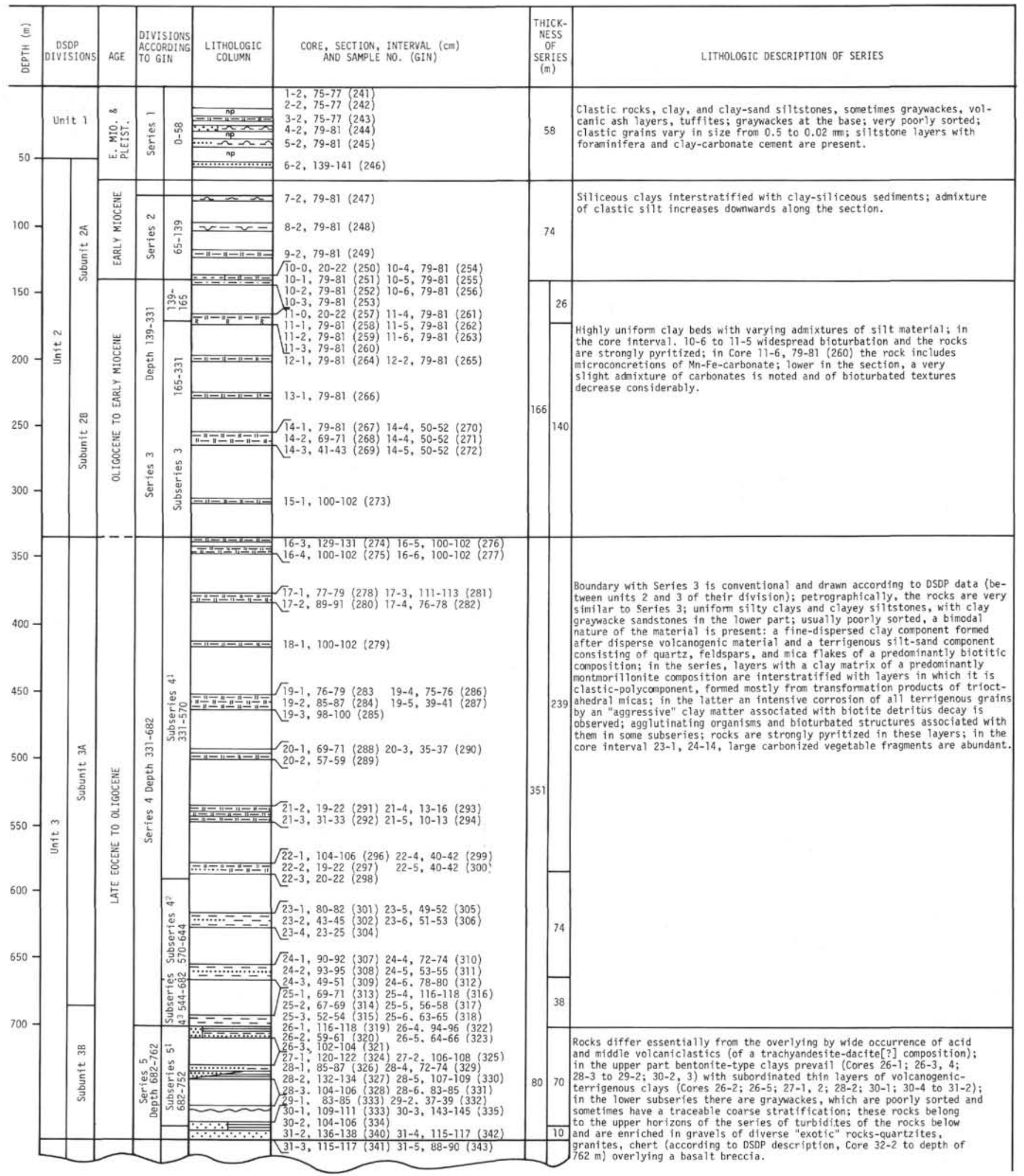

Figure 1. Series designations and sediment characteristics, Site 345.

grains. Zeolites are absent, and this can be apparently attributed either to the "share" contributed by fresh volcanic glass, or, perhaps, to a change in its composition (higher in the section there are more alkaline and basic [?] glasses which, in fact, enable zeolite to be formed).

A possible alteration of volcaniclastics is reflected in the character of montmorillonites, which changes 


\begin{tabular}{|c|c|}
\hline PETROGRAPHIC DESCRIPTION OF SUBSERIES AND LAYERS & ASSOCIATIONS OF CLAY AND AUTHIGENIC MINERALS \\
\hline $\begin{array}{l}\text { The composition of clastic material is quartz, plagioclases, micas of } \\
\text { a predoninantly biotitic composition, sometimes indented-dissolved } \\
\text { pyroxene and amphibole grains, single grains of zircon and garnet; } \\
\text { glass fragments are numerous; a varying composition of the clay } \\
\text { matrix is typical: from clastic, associated with decay of triocta- } \\
\text { hedral micas, to volcanogenic, mostly represented by montmorillonite. }\end{array}$ & $\begin{array}{l}\text { Alternation of a polycomponent association of clay minerals associated with } \\
\text { biotite decay - a typical ganut of chlorite-vermiculite-montmorillonite } \\
\text { mingerals with re latively pure aluminum, slightly ferruginous predominantly } \\
12 \AA \text { (Na- } K \text { )-montmorillonites of a bentonite type. }\end{array}$ \\
\hline 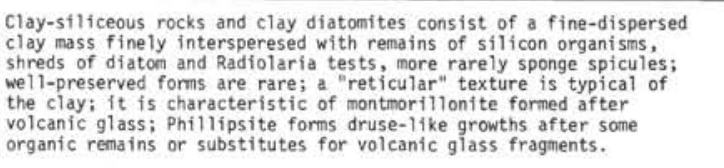 & 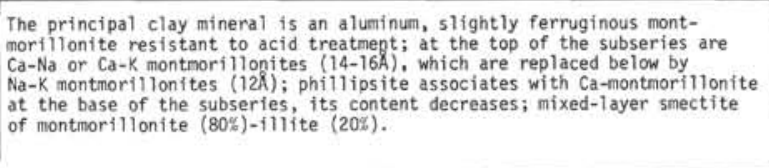 \\
\hline $\begin{array}{l}\text { Polycomponent-montmorillonite clays, often intensively pyritized: } \\
\text { in the pyritized rocks the role of kaolinites is somewhat increased; } \\
\text { an intensive development of bioturbated textures; clastogenic clay } \\
\text { layers consisting mostly of trioctahedral micas decay products. }\end{array}$ & $\begin{array}{l}\text { Principal mineral is an aluninum, slightly ferruginous predominantly } \\
\text { Na-k (12 } 2 \text { ) montmorillonite; abundant accumulations of globular } \\
\text { pyrite. }\end{array}$ \\
\hline $\begin{array}{l}\text { In the top of the subseries there is an unusual Fe-montmorillonite } \\
\text { rock with } 0.02-0.05 \text { mim sized rosettes of Fe-rhodochrosite or Mn- } \\
\text { siderite; below the same polycomponent, montmorillonite clays are } \\
\text { found as in subseries } 3^{1} \text {. }\end{array}$ & 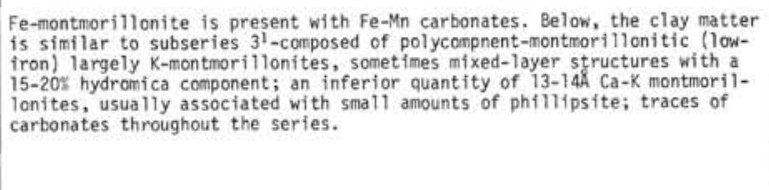 \\
\hline 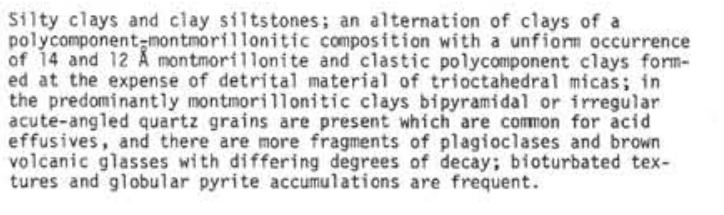 & $\begin{array}{l}\text { Alternating predominantly } 14 \text { and } 12 \AA \text { montmorillonite (polycomponent- } \\
\text { montmorilionite) clays and clastic polycomponent clays-decay products } \\
\text { of trioctahedral hydromicas. }\end{array}$ \\
\hline 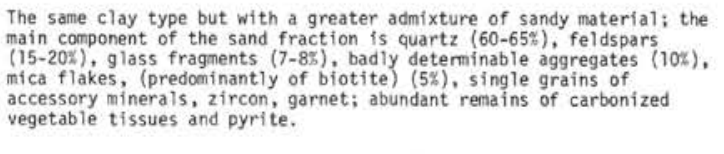 & $\begin{array}{l}\text { The same composition as the overlying clays with an increased kaolinite } \\
\text { content. }\end{array}$ \\
\hline $\begin{array}{l}\text { Alternating predominantly montmorillonitic clays with "reticular" } \\
\text { texture and clastic polycomponent clays. }\end{array}$ & $\begin{array}{l}\text { The same composition of clays as in subseries } 4^{1} \text {, with a greater amount of } \\
\text { predominantly montmorillonitic clays. }\end{array}$ \\
\hline $\begin{array}{l}\text { Predominance of montmorillonite clays after altered volcanogenic } \\
\text { glasses; an alternation is observed of the intensivively birefringent } \\
\text { montmorillonites and optically poorly crystallized, weakly polar- } \\
\text { izing, sometimes nearly isotopic ones; in sone rocks, phenocrysts } \\
\text { of plagioclases, bipyramidal quartz, iarge biotite plates are } \\
\text { present; clastic clays occur as subordinate thin layers. }\end{array}$ & $\begin{array}{l}\text { At the top, predominantly Na (12A), at the base } \mathrm{Ca}(14-14.5 \AA) \text { aluminum low- } \\
\text { iron montmorillonites of bentonite type, resistant to acid treatment; sub- } \\
\text { ordinate thin layers of clays of the composition-montmorillonite-poly- } \\
\text { component biotite transformation products. }\end{array}$ \\
\hline $\begin{array}{l}\text { Graywackes, poorly sorted; the dominant component of the clastic } \\
\text { material is "platform"-type quartz, with occurrence of intert } \\
\text { mediate and basic plagioclases and abundance of biotite. The } \\
\text { matrix is a Ca-Na aluminum, slightly ferruginous montmorillonite } \\
\text { and more rarely a mixture of montmorillonite and polycomponent } \\
\text { decay products of trioctahedral micas; a bimodal character is a } \\
\text { conspicuouss-mixture of clastic matter supplied from continent } \\
\text { and volcaniclastics. }\end{array}$ & \\
\hline
\end{tabular}

Figure 1. (Continued). 
TABLE 1

Results of X-Ray Structural Analysis of Samples from Site 345, Leg 38

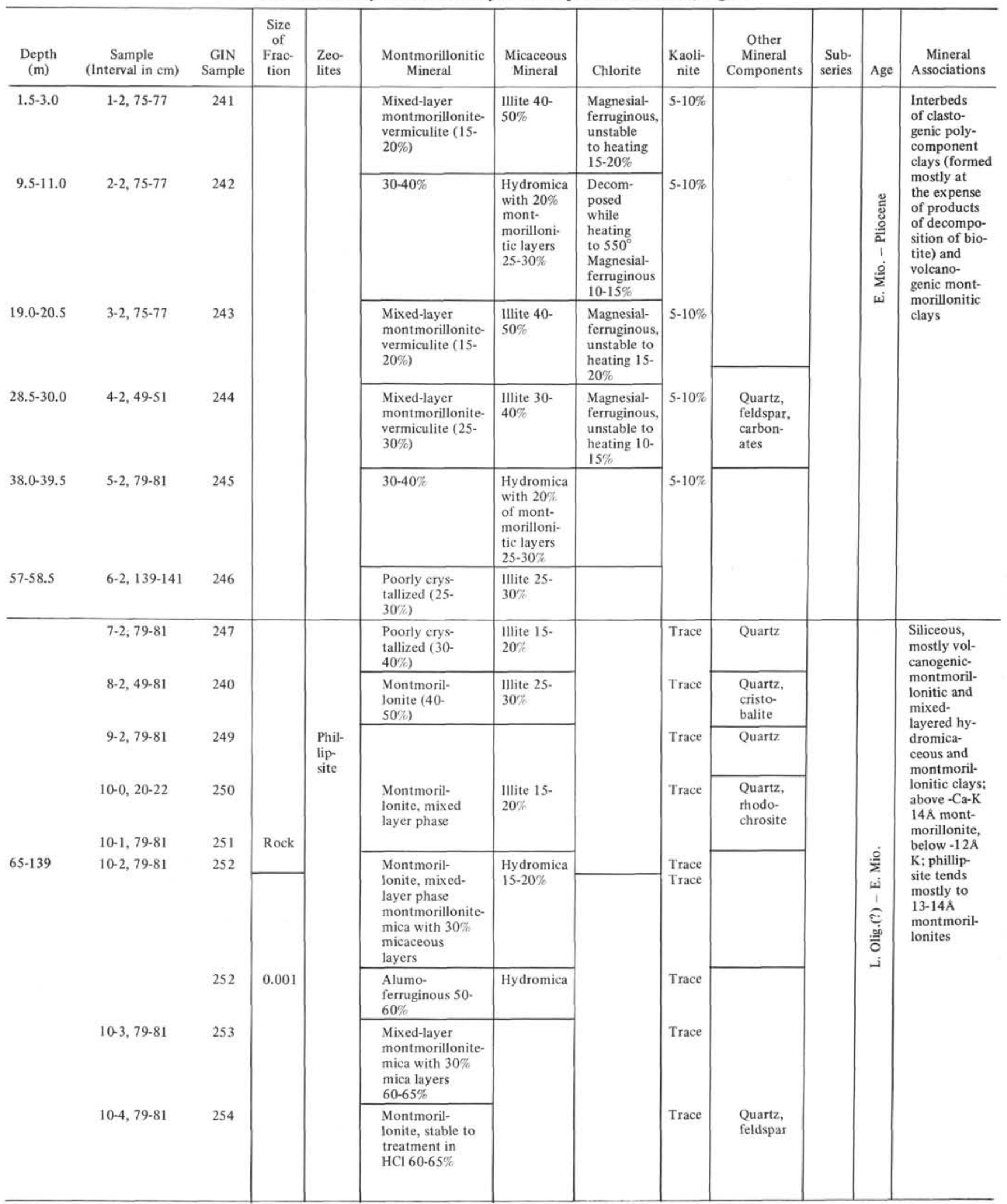


TABLE 1 - Continued

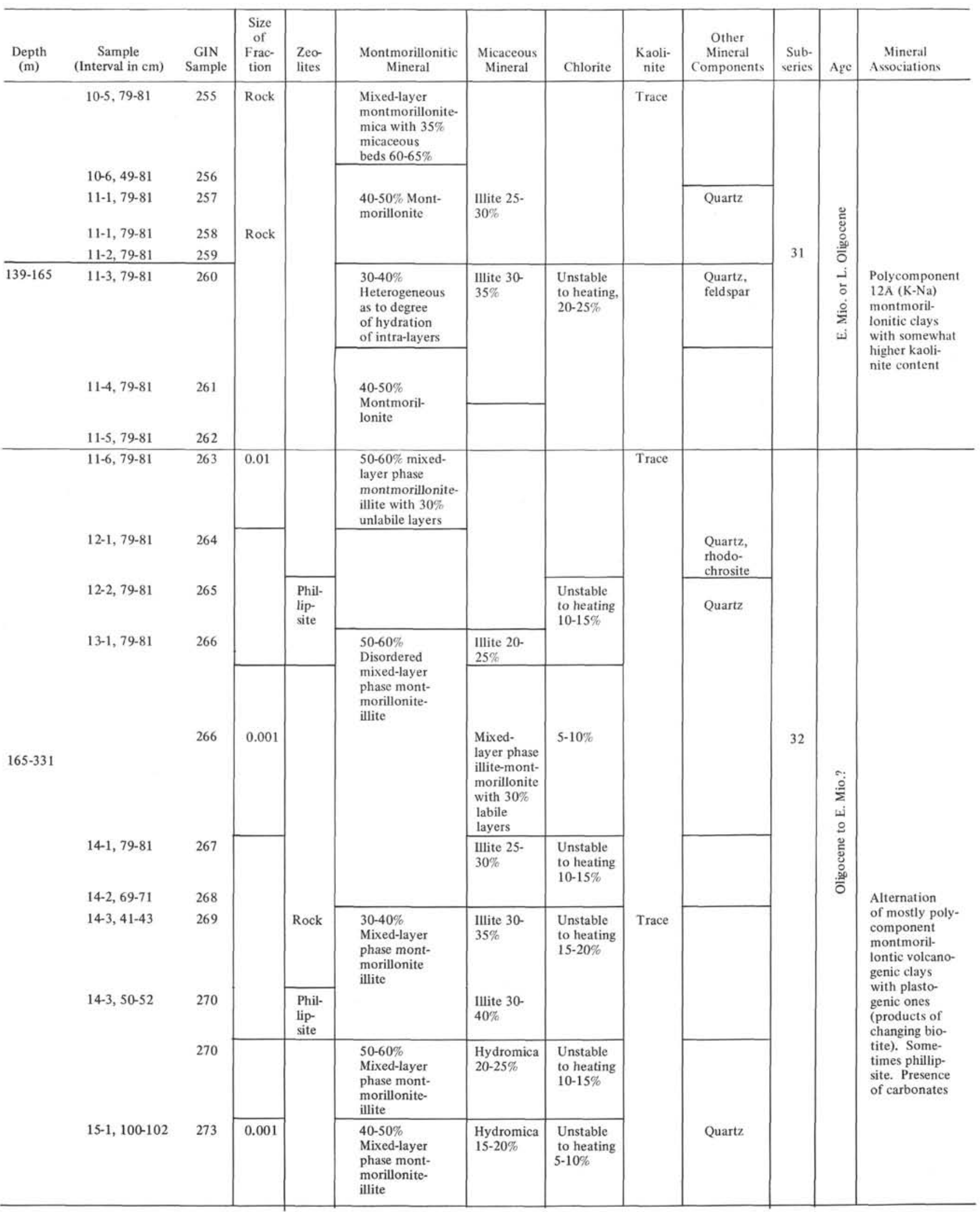


TABLE 1 - Continued

\begin{tabular}{|c|c|c|c|c|c|c|c|c|c|c|c|c|}
\hline $\begin{array}{l}\text { Depth } \\
\text { (m) }\end{array}$ & $\begin{array}{c}\text { Sample } \\
\text { (Interval in } \mathrm{cm} \text { ) }\end{array}$ & $\begin{array}{c}\text { GIN } \\
\text { Sample }\end{array}$ & $\begin{array}{l}\text { Size } \\
\text { of } \\
\text { Frac- } \\
\text { tion }\end{array}$ & $\begin{array}{l}\text { Zeo- } \\
\text { lites }\end{array}$ & $\begin{array}{l}\text { Montmorillonitic } \\
\text { Mineral }\end{array}$ & $\begin{array}{l}\text { Micaceous } \\
\text { Mineral }\end{array}$ & Chlorite & $\begin{array}{l}\text { Kaoli- } \\
\text { nite }\end{array}$ & $\begin{array}{c}\text { Other } \\
\text { Mineral } \\
\text { Components }\end{array}$ & $\begin{array}{l}\text { Sub- } \\
\text { series }\end{array}$ & Age & $\begin{array}{c}\text { Mineral } \\
\text { Associations }\end{array}$ \\
\hline \multirow{3}{*}{$331-570$} & $18-1,100-102$ & 279 & Rock & & $30-40 \%$ & $\begin{array}{l}\text { Illite } 30- \\
40 \%\end{array}$ & $\begin{array}{l}\text { Unstable } \\
\text { to heating }\end{array}$ & $10-15 \%$ & \multirow{3}{*}{ Quartz } & \multirow{3}{*}{41} & \multirow[b]{3}{*}{$\begin{array}{l}\text { ¿ूँ } \\
\text { : } \\
\text { 。ँ }\end{array}$} & \multirow{3}{*}{$\begin{array}{l}\text { Alternation } \\
\text { of volcano- } \\
\text { genic poly- } \\
\text { component- } \\
\text { montmoril- } \\
\text { lonitic and } \\
\text { clastic poly- } \\
\text { component } \\
\text { clays (prod- } \\
\text { ucts of chang- } \\
\text { ing biotite) }\end{array}$} \\
\hline & & 279 & 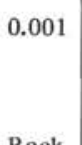 & & $\begin{array}{l}40-50 \% \\
\text { Mixed-layer } \\
\text { phase mont- } \\
\text { morillonite }\end{array}$ & $\begin{array}{l}\text { Illite 25- } \\
30 \%\end{array}$ & $\begin{array}{l}\text { Unstable } \\
\text { to heating } \\
15-20 \%\end{array}$ & Trace & & & & \\
\hline & $\begin{array}{l}17-2,85-91 \\
19-2,85-87\end{array}$ & $\begin{array}{l}280 \\
284\end{array}$ & $\begin{array}{l}\text { Rock } \\
\text { Rock }\end{array}$ & & $\begin{array}{l}50-60 \% \\
\text { phase mont- } \\
\text { morillonite- } \\
\text { illite }\end{array}$ & $\begin{array}{l}\text { Illite 20- } \\
25 \%\end{array}$ & $\begin{array}{l}\text { Unstable } \\
\text { to heating } \\
10-15 \%\end{array}$ & Trace & & & & \\
\hline \multirow{5}{*}{$682-762$} & $26-1,116-118$ & 319 & \multirow{3}{*}{\multicolumn{2}{|c|}{ Rock }} & $\begin{array}{l}40-50 \% \text { Mont- } \\
\text { morillonite }\end{array}$ & $\begin{array}{l}\text { Illite 25- } \\
30 \%\end{array}$ & & $5-10 \%$ & \multirow{3}{*}{$\begin{array}{l}\text { Quartz } \\
\text { (little) } \\
\text { carbon- } \\
\text { ates }\end{array}$} & \multirow{8}{*}{51} & \multirow{8}{*}{ 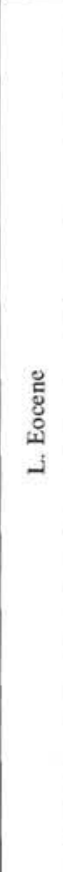 } & \multirow{8}{*}{$\begin{array}{l}\mathrm{Ca} \text { and } \mathrm{Na}-\mathrm{K} \\
\text { montmoril- } \\
\text { lonitic volcan- } \\
\text { ogenic, often } \\
\text { almost mono- } \\
\text { mineral slight- } \\
\text { ly ferruginous- } \\
\text { aluminic ben- } \\
\text { tonitic type }\end{array}$} \\
\hline & $26-3,102-104$ & 321 & & & $\begin{array}{l}90-95 \% \text { Mont- } \\
\text { morillonite }\end{array}$ & & & & & & & \\
\hline & $26-4,94-96$ & 322 & & & $\begin{array}{l}30-40 \% \text { Mont- } \\
\text { morillonite }\end{array}$ & $\begin{array}{l}\text { Illite } 30- \\
40 \%\end{array}$ & $\begin{array}{l}\text { Unstable } \\
\text { to heating } \\
25-30 \%\end{array}$ & & & & & \\
\hline & $28-1,85-87$ & 326 & \multirow{2}{*}{ Rock } & $\begin{array}{l}\text { Phil- } \\
\text { lip- } \\
\text { site }\end{array}$ & \multirow{4}{*}{$\begin{array}{l}90-95 \% \\
\text { Montmorillonite }\end{array}$} & & \multirow{4}{*}{$\begin{array}{l}\text { Unstable } \\
\text { to heating } \\
2-5 \%\end{array}$} & & \multirow[t]{2}{*}{$\begin{array}{l}\text { Quartz } \\
\text { (little) }\end{array}$} & & & \\
\hline & $28-4,72-74$ & 329 & & & & & & & & & & \\
\hline & $30-2,104-106$ & 337 & \multirow[t]{3}{*}{ Rock } & & & & & & & & & \\
\hline & $30-5,143-145$ & 339 & & & & & & & & & & \\
\hline $752-762$ & $31-4,115-117$ & 342 & & & $\begin{array}{l}80-90 \% \\
\text { Montmorillonite }\end{array}$ & Illite $5-10 \%$ & $\begin{array}{l}\text { Unstable } \\
\text { to heating } \\
5-10 \%\end{array}$ & & & & & \\
\hline
\end{tabular}

deeper in the sediment section. In the diffraction pattern for Sample 247, the first basal reflection has $d_{(001)}=14-16 \AA$, and glycerine-saturated reflection is $d_{(001)}=19 \AA$. This is an indication that the material and the montmorillonite are poorly crystallized. There is also a likelihood of sorption of amorphous $\mathrm{SiO}_{2}$. The abundance of amorphous material (uncrystallized glass or opal?) is also indicated on the diffraction pattern by a broad halo in the region of $d$ from 4.5 to $3 \AA$. Soda treatment of the sample substantially improves the resolution of the small-angle montmorillonite reflection. For samples 248-251, $d_{(001)}$ of montmorillonite is equal to $13.4-13.8 \AA$. This is attributed to sorption, by montmorillonite interlayers, of $\mathrm{Ca}$ and $\mathrm{Na}$ and possibly K.

Lower in the section, $d_{(001)}$ montmorillonite reflection gradually falls to $12.6 \AA$, and then to $12 \AA$. This indicates an increasing share of $\mathrm{Na}$ and $\mathrm{K}$ in the general exchange complex. Analysis of the diffraction patterns for glycerine-saturated preparations shows that the montmorillonite component consists not only of montmorillonite, but also of mixed-layer montmorilloniteillite containing from $10 \%$ to $30 \%$ micaceous layers.

An admixture of a small amount of well-crystallized mica, kaolinite, quartz, and feldspars is present in all clays. Zeolites appear on X-ray patterns only in the upper $14 \AA$. Ca-Na-montmorillonite clays have poor

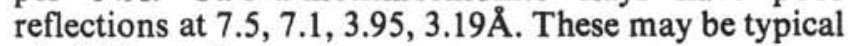
of phillipsite. ${ }^{2}$

${ }^{2}$ Reflection $d=7.5 \AA$ may also belong to another type of zeolite. It is hoped to establish this during further special investigation of zeolites. 
In contrast to clays typical for continental terrigenous units, the compositions of the less than $0.001 \mathrm{~mm}, 0.001-0.01 \mathrm{~mm}$ fractions, as well as the bulk composition are almost identical. This indicates that montmorillonite is the basic component of all size fractions and was formed in situ. It differs from typical pelagic Fe-montmorillonites by its resistance to an acid treatment. Judging from the chemical composition (Table 2, Sample 252), it can be assumed the montmorillonite developed from a volcanic glass less basic than tholeiitic basalts (of a trachyte-andesite composition?). This seems to be indicated by a rather low iron content $\left(\mathrm{Fe}_{2} \mathrm{O}_{3}+\mathrm{FeO}\right.$ about $6 \%$, Table 1). The content of $\mathrm{K}_{2} \mathrm{O}$ and $\mathrm{Na}_{2} \mathrm{O}$ in the bulk sample are approximately equal $\left(\mathrm{Na}_{2} \mathrm{O}=2.37 \%, \mathrm{~K}_{2} \mathrm{O}=2.13 \%\right)$. This is either a sign of an incomplete decomposition of glasses, or additional evidence confirming that montmorillonite was formed in the marine environment and not on the continent. $\mathrm{Na}$ is usually easily washed out during the montmorillonitization of volcaniclastics in fresh water basins.

Series 3 (Oligocene to early Miocene [?], Cores 10-6 to 15-6, Samples 256-273, depth 139-331 m)

This series corresponds to Subunit 2B of the shipboard designations. The sediments are highly uniform and are generally clays with a varying admixture of siltsized material. Montmorillonitized ash layers are pressent. A great number of layers are bioturbated. Some layers are enriched in carbonaceous detritus and pyritized. The series has two subseries, $3_{1}$ and 32 .

Subseries 31 (Late Oligocene or Early Miocene, Cores 10-6 to 11-5, Samples 256-262, depth 140-165 m)

The subseries consists of highly uniform, predominantly montmorillonitic clays, with a constant but small admixture of terrigenous material with subordinate layers of silt-sized clastic clays. Bioturbation textures are typical. Numerous burrows and peculiar "loaves" are present. The "loaves" are oval, sometimes elongate-irregular structures $(0.1-1 \mathrm{~mm})$ and have agglutinized (?) rims, consisting of irregular small quartz grains, feldspar fragments, glasses, and sometimes zeolites $(0.02-0.08 \mathrm{~mm})$. These features may have a "vermiculite" texture (i.e., exfoliated) up to 1.5 $\mathrm{mm}$ long and about $0.06 \mu \mathrm{m}$ thick. The internal nucleus consists of a rather pure, fine-aggregate of strongly birefringent clay material, as if "purged" of alien admixtures. Single specimens of these features are present in the lower part of the preceding series, but they have their maximum abundance in Subseries 31 . The bioturbation textures are accompanied by large irregular accumulations of globular pyrite.

A typical example of clastic clay with numerous "loaves" and "agglutinate worms," strongly pyritized, is present in Sample 11-3, 79-81 cm (Sample 260). The $\mathrm{X}$-ray pattern is typical of mixed-layer clay. Similar to Samples 241,243 , and 244 , the diffraction pattern contains a broad maximum lying in the region of $d_{(001)}$ ranging from 11 to $14 \AA$. The basal reflections of illite with $d_{(001)}=10 \AA$ are clearly seen, and the basal reflections of kaolinite on the diffraction patterns of both the bulk sample and the less than $0.01 \mathrm{~mm}$ fraction are markedly intensive. Montmorillonite in the less than
$0.01 \mathrm{~mm}$ fraction is represented by $\mathrm{K}$-difference, as is suggested by the value of $d_{(001)}=11.6 \AA$. The iron content in the mineral structure is very low, which accounts for its resistance to $\mathrm{HCl}$. The chemical composition of the sediment indicates a high $\mathrm{Al}_{2} \mathrm{O}$ content recalculated for silicon-free substance $(21.80 \%)$, which is in accord with the presence of kaolinite (Table 2). Abundant traces of intensive organic activity and high degree of pyritization, which often develops on organic remnants.

\section{Subseries $3_{2}$ (Oligocene, Cores 11-6 to 15-6, Samples 263-273, depth 165-295 m)}

A bed of predominantly mixed-layer montmorillonitic clays with $\mathrm{Mn}$ - $\mathrm{Fe}$-carbonates. In the subseries (Sample 11-6, 79-81 cm, Sample 263), a peculiar clay with microconcretions of manganosiderite or $\mathrm{Fe}$ rhodochrosite is present. In the aggregate-polarizing clay mass, microconcretions of $\mathrm{Mn}-\mathrm{Fe}$-carbonate (0.02$0.05 \mathrm{~mm}$ ) and having a rose-like form are densely scattered. In the central part of some of the microconcretions there are pyrite inclusions. The chemical composition (Table 2, Sample 263) is marked by a high iron content $\left(\mathrm{Fe}_{2} \mathrm{O}=9.24 \%, \mathrm{FeO}=2.15 \%\right)$ and an increased manganese content $(\mathrm{Mn}=0.85 \%){ }^{3}$

Lower in the subseries, uniform sediments consist predominantly of montmorillonite clays with an admixture of silt-size quartz grains (often with an acuteangle or bipyramidal shape, a shape characteristic of acid extrusives), rare tablet-shaped fragments of intermediate and calcic plagioclases, brown palagonitized glasses, and mica flakes. There are occasional bioturbation textures, accumulations of globular pyrite, and leucoxene clots. The X-ray patterns resemble those of the less than 0.01 and $0.001 \mathrm{~mm}$ fraction. The sole difference is that the latter has a smaller admixture of micas, kaolinite, and quartz. Phillipsite reflections are fixed in some samples (Samples 264, 265, 266, 270).

Chemical characteristics of the sediments are similar to those of the clays of the upper portions of Subseries 31. They differ solely in having a greater $\mathrm{SiO}_{2}$ content due to a great amount of terrigenous quartz (Table 1, Sample 266).

\section{Series 4 (Oligocene to late Eocene [?], Cores 16-1 to 26-} 6)

The boundary of the series is unimportant as the sediments are so similar to Series 3 that it is unnecessary to assume any boundary between the series. These are highly uniform silty and sandy clays, clay siltstones, and sandstones. Agglutinized organisms, and likely traces of silt-eaters, probably developed the bioturbation in some interlayers. In some layers, there are abundant carbonized remains and pyrite. Three subseries are distinguished.

Subseries 4 1 (Core 16-22-6, Samples 274-300, depth 335-370 m)

Clays and clayey siltstones. The composition of the clays is a clastic mixed-layer clay associated with biotite alteration products, with layers of mixed-layermontmorillonitic clays. Abundant clastic material of

${ }^{3}$ Recalculated in terms of silicon-free substance. 
TABLE 2

Chemical Composition of Samples, Site 345

\begin{tabular}{|c|c|c|c|c|c|c|c|c|c|c|c|c|c|c|c|c|c|c|c|c|}
\hline \multirow{4}{*}{$\begin{array}{c}\text { Age } \\
\text { Series } \\
\text { Subseries } \\
\begin{array}{l}\text { No. of } \\
\text { Sample }\end{array}\end{array}$} & \multirow{2}{*}{\multicolumn{2}{|c|}{$\begin{array}{c}\text { Early Miocene } \\
\text { Series } 2\end{array}$}} & \multicolumn{6}{|c|}{ Oligocene to Early Miocene } & \multicolumn{12}{|c|}{ Late Eocene to Oligocene } \\
\hline & & & \multicolumn{6}{|c|}{ Series 3} & \multicolumn{4}{|c|}{ Series 4} & \multicolumn{8}{|c|}{ Series 5} \\
\hline & & & \multicolumn{2}{|c|}{$3_{1}$} & \multicolumn{3}{|c|}{${ }^{3} 2$} & & \multicolumn{2}{|c|}{${ }_{1}{ }_{1}$} & \multicolumn{2}{|c|}{${ }_{2}$} & \multicolumn{2}{|c|}{$5_{1}$} & \multicolumn{2}{|c|}{$5_{1}$} & \multicolumn{2}{|c|}{$5_{1}$} & \multicolumn{2}{|c|}{$5_{2}$} \\
\hline & 252 & $252^{\mathrm{a}}$ & 260 & $260^{\mathrm{a}}$ & 263 & $263^{\mathrm{a}}$ & 266 & $266^{\mathrm{a}}$ & 280 & $280^{a}$ & 302 & $302^{\mathrm{a}}$ & 321 & $321^{\mathrm{a}}$ & 329 & $329^{\mathrm{a}}$ & 331 & $331^{a}$ & 341 & $341^{\mathrm{a}}$ \\
\hline $\begin{array}{c}\text { Compo- } \\
\text { nents }\end{array}$ & \multicolumn{2}{|c|}{ Rock } & \multicolumn{2}{|c|}{ Rock } & \multicolumn{4}{|c|}{ Fraction $<0.001 \mathrm{~mm}$} & \multicolumn{2}{|c|}{ Rock } & \multicolumn{2}{|c|}{ Rock } & \multicolumn{2}{|c|}{ Rock } & \multicolumn{2}{|c|}{ Rock } & \multicolumn{2}{|c|}{ Rock } & \multicolumn{2}{|c|}{ Rock } \\
\hline $\mathrm{SiO}_{2}$ & 53.30 & 48.30 & 53.47 & 46.35 & 51.62 & 46.13 & 58.19 & 50.02 & 54.94 & 45.70 & 54.09 & 48.85 & 44.72 & 43.20 & 54.96 & 52.00 & 55.72 & 46.30 & 63.35 & 46.20 \\
\hline $\mathrm{TiO}_{2}$ & 1.01 & 1.12 & 1.02 & 1.17 & 0.52 & 0.58 & 0.96 & 1.14 & 1.03 & 1.24 & 0.74 & 0.84 & 0.63 & 0.64 & 0.65 & 0.70 & 0.68 & 0.83 & 1.13 & 1.64 \\
\hline $\mathrm{Al}_{2} \mathrm{O}_{3}$ & 16.66 & 18.55 & 18.95 & 21.80 & 16.29 & 18.22 & 14.81 & 17.56 & 16.54 & 19.74 & 14.99 & 17.00 & 14.43 & 14.70 & 15.90 & 17.00 & 15.67 & 19.10 & 15.27 & 22.19 \\
\hline $\mathrm{Fe}_{2} \mathrm{O}_{3}$ & 5.39 & 6.00 & 3.16 & 3.64 & 8.25 & 9.24 & 4.38 & 5.20 & 5.36 & 6.44 & 9.13 & 10.36 & 5.65 & 5.75 & 3.84 & 4.11 & 4.21 & 5.12 & 3.16 & 4.59 \\
\hline $\mathrm{FeO}$ & 0.92 & 1.20 & 1.30 & 1.50 & 1.92 & 2.15 & 1.07 & 1.27 & 2.34 & 2.81 & 1.33 & 1.51 & 0.42 & 0.43 & 0.81 & 0.87 & 0.47 & 0.57 & 1.59 & 2.31 \\
\hline $\mathrm{CaO}$ & 0.59 & 0.66 & 0.38 & 0.44 & 1.48 & 1.66 & 0.52 & 0.62 & 0.69 & 0.83 & 1.02 & 1.5 & 8.33 & 8.48 & 1.82 & 1.95 & 3.27 & 2.64 & 0.87 & 1.26 \\
\hline $\mathrm{MgO}$ & 2.11 & 2.34 & 1.98 & 2.28 & 1.72 & 1.92 & 2.11 & 2.50 & 1.89 & 2.27 & 1.56 & 1.77 & 1.80 & 1.82 & 2.36 & 2.52 & 2.42 & 2.97 & 1.63 & 2.36 \\
\hline $\mathrm{MnO}$ & 0.04 & 0.04 & 0.04 & 0.05 & 0.76 & 0.85 & 0.03 & 0.04 & 0.03 & 0.04 & 0.02 & 0.02 & 1.15 & 1.17 & 0.12 & 0.13 & 0.15 & 0.18 & 0.05 & 0.07 \\
\hline $\mathrm{Na}_{2} \mathrm{O}$ & 2.37 & 2.64 & 1.99 & 2.29 & 0.57 & 0.64 & 2.25 & 2.67 & 1.69 & 2.03 & 1.46 & 1.65 & 1.69 & 1.72 & 2.18 & 2.33 & 1.84 & 2.24 & 1.06 & 1.54 \\
\hline $\mathrm{K}_{2} \mathrm{O}$ & 2.13 & 2.37 & 2.67 & 2.96 & 2.44 & 2.73 & 2.10 & 2.59 & 2.69 & 3.23 & 1.67 & 2.89 & 0.70 & 0.71 & 1.46 & 1.56 & 1.56 & 1.90 & 2.69 & 3.91 \\
\hline $\mathrm{H}_{2} \mathrm{O}+$ & 6.57 & 7.30 & 8.08 & 9.30 & 6.49 & 7.26 & 6.49 & 7.70 & 6.01 & 7.20 & 3.33 & 3.78 & 4.44 & 4.52 & 4.69 & 6.02 & 4.21 & 5.13 & 5.61 & 3.24 \\
\hline $\mathrm{H}_{2} \mathrm{O}-$ & 6.80 & 7.56 & 5.72 & 6.58 & 5.87 & 6.57 & 5.92 & 7.02 & 5.42 & 6.50 & 5.6 & 6.45 & 9.76 & 9.95 & 10.17 & 10.90 & 9.54 & 11.60 & 3.46 & 5.03 \\
\hline $\mathrm{CO}_{2}$ & 0.07 & 0.08 & 0.24 & 0.28 & 1.21 & 1.36 & & - & 0.12 & 0.14 & 0.17 & 0.19 & 6.45 & 6.55 & 0.25 & 0.27 & 0.72 & 0.88 & - & - \\
\hline C & 0.40 & 0.45 & 0.13 & 0.15 & 0.34 & 0.38 & 0.26 & 0.31 & 0.41 & 0.49 & - & - & - & - & 0.06 & 0.06 & - & - & - & - \\
\hline $\mathrm{P}_{2} \mathrm{O}_{5}$ & 0.06 & 0.07 & 0.05 & 0.06 & 0.27 & 0.30 & 0.05 & 0.06 & 0.06 & 0.07 & 0.04 & 0.05 & 0.06 & 0.06 & 0.04 & 0.04 & 0.05 & 0.05 & 0.11 & 0.16 \\
\hline $\mathrm{Cl}$ & 1.40 & 1.56 & 1.00 & 1.15 & - & - & 1.08 & 1.28 & 0.68 & 0.82 & 0.32 & 0.36 & 0.27 & 0.27 & 0.43 & 0.46 & 0.30 & 0.37 & 0.31 & 0.45 \\
\hline $\mathrm{S}_{\mathrm{Fe}_{2} \mathrm{~S}}$ & - & - & - & - & - & - & - & - & - & - & 37.0 & 4.19 & - & - & - & - & 0.09 & 0.11 & 0.10 & 0.15 \\
\hline $\mathrm{SO}_{3}$ & - & - & - & - & - & - & - & - & 0.39 & 0.47 & 1.15 & 1.30 & - & - & - & - & - & - & - & - \\
\hline$\Sigma$ & 99.82 & 100.06 & $100^{n x}$ & 100.00 & 99.75 & 99.98 & 100.22 & 99.88 & 100.18 & 100.02 & 101.82 & 101.70 & 100.50 & 99.77 & 99.74 & 99.92 & 99.80 & 100.04 & 100.39 & 100.10 \\
\hline $\mathrm{SiO}_{2} \mathrm{qw}$ & 8.50 & - & 12.16 & - & 9.28 & - & 13.04 & - & 15.84 & - & 12.54 & - & 0.98 & - & 5.20 & - & 16.66 & - & 30.60 & - \\
\hline $\mathrm{SiO}_{2}$ am & 1.40 & - & 1.05 & - & 1.15 & - & 2.80 & - & 1.05 & - & 1.05 & - & 1.26 & - & 1.06 & - & 1.05 & - & 0.98 & - \\
\hline
\end{tabular}

Note: Sample $252=10-2,79-81 \mathrm{~cm}$, siliceous montmorillonitic clay; Sample $260=11-3,79-81 \mathrm{~cm}$, silty mixed-layer clay (products of decomposition of trioctahedral micas) with pyrite; Sample $263=$ $11-6,79-81 \mathrm{~cm}$, ferrimontmorillonitic clay with micronodules, Fe-M-carbonate; Sample $266=13-1,79-81 \mathrm{~cm}$, silty clay, mostly montmorillonitic, with phillipsite; Sample $280=17-2,89-91 \mathrm{~cm}$, silty mixed-layer montmorillonitic clay with pyrite; Sample $302=23-2,43-45 \mathrm{~cm}$, silty mixed-layer clay; Sample $321=26-3,102-104 \mathrm{~cm}$, an interbed of slightly montmorillonitized glass, plagioclases are replaced by calcite; Sample $329=28-4,72-74 \mathrm{~cm}$, an interbed of montmorillonitized glass; Sample $331=28-6,83-85 \mathrm{~cm}$, bentonite-like clay; Sample $341=31-3,115117 \mathrm{~cm}$, graywacke.

${ }^{\mathrm{a}}$ Evaluated for nonsiliceous substance. 
silt or sometimes fine sand size is comprised of quartz, tablet, or angular shaped grains of plagioclase (predominantly of an intermediate or calcic composition, seldom albite), albite-oligoclase, and sporadic single, fragmentary microcline grains. There is a considerable amount of variously altered and fresh, single green-brown fragments of volcanic glasses $(n \sim 1.53$ 1.55 ), and biotite flakes with differing degree of alteration. Micaceous minerals are so abundant, that the clay material has a pronounced mixed-layer composition. This is usually formed during decomposition of trioctahedral micas, with approximately equal contents of montmorillonite, hydromica, and a small amount of kaolinite (Sample 276). In some samples, it is not the bulk sample but even the less than $0.001 \mathrm{~mm}$ fraction that is clastic. In Cores $16-3$ to $17-2$, intensively developed bioturbation reappears, with agglutinized organic remains, small additions of pyrite, and leucoxene clots.

The altered nature of the clays, and, in particular, the biotite micas, is reflected in the chemical composition (Table 2, Sample 280). The $\mathrm{Al}_{2} \mathrm{O}_{3}$ content increases, and $\mathrm{K}_{2} \mathrm{O}(3.23 \%)$ exceeds $\mathrm{Na}_{2} \mathrm{O}$ by 1.5 times $(2.03 \%)$. Lower in the series silty clays reappear, but there are few agglutinized organic remains.

\section{Subseries 42 (Cores 23 to 24-4, Samples 301-310, depth 571-641 m)}

The siltstone contains clays of a mixed-layer composition and abundant carbonized vegetable remains. The carbonized material has a perfectly preserved cellulose structure. The rocks are strongly pyritized. The subseries seems to have been formed under conditions dominated by a high terrigenous influx.

\section{Subseries 43 (Cores 24-25-6, Samples 307-318, depth 641-683 m)}

The composition is similar to Subseries 31. Bioturbation textures were observed in many samples.

\section{Series 5 (Cores 26-1 to 32-2, depth 683-762 m)}

This part of the sediment section should be treated as an independent series. There is a prevalence of volcanogenic material and frequent interlayers of glasses more or less reworked into a slightly ferruginous-aluminum montmorillonite. Two subseries are clearly distinguished.

\section{Subseries 51 (Cores 26-1 to 31-2, Samples 319-340, depth 683-752 m)}

A subseries of specific, nearly monomineralic, montmorillonite clays developed after volcanic glasses. An alternation is observed of montmorillonites which are intensively polarized in yellow-orange light, with almost isotropic optically slightly crystallized ones. No difference of X-ray structures of the minerals is observed. All the montmorillonites belong to the aluminum low-iron difference and seem to have been formed at the expense of volcanic products of a rather acid and apparently alkaline trachyte-andesite composition. Idiomorphic inclusions of plagioclases and large biotite plates are present in some samples. Plagioclases are sometimes replaced by calcite or mariganocalcite, which is indicated by a higher Mn content in all samples (Table 1, Samples 321, 329, 331).

Subseries $5_{2}$ (Cores 31-3 to 32-3, Samples 341, 342-343)

Graywackes forming the upper part of the layers make up the base of this sedimentary series. According to the Site Report (this volume), beneath the graywackes, rocks are present containing rounded "exotic" pebbles of quartzite, granites, and limestones.

A dual nature of the components is conspicuous in the graywackes. The sand fraction is characterized by a high quartz content. According to Simanovich (personal communication) the quartz association of Sample 342 consists of: metamorphic quartz $=65 \%$, quartz of "ancient" granitoids $=8 \%$, quartz of "young" granitoids $=6 \%$, and vein quartz $=21 \%$.

The distribution pattern indicates a typical quartz association of quartz of crystalline schists and sandy rocks of platforms. Many grains are well rounded, and regeneration rims are frequent. This indicates that a part of the quartz was supplied from a sedimentary platform. The clay component has a nearly monomineral montmorillonite composition and is undiscernible from montmorillonite clays in the overlying subseries, which are bentonites (Sample 342).

\section{PRINCIPAL RESULTS AND CONCLUSIONS}

1. Five series have been distinguished on the basis of mineralogic-petrographic features.

2. Series 1 is characterized by the conspicuously "polygenetic" (bimodal) nature of the sediments, which has been derived from terrigenous and volcanic sources.

The composition of the clastic quartz (Simanovich, personal communication) indicates the presence of a typical association of quartz from ancient metamorphic rocks of shields and sedimentary sandstones. This quartz association is genetically related to the clastic polycomponent nature of the clays and the matrix graywacke, which are for the most part alteration products of biotite micas. Noteworthy is the small role of chlorite in biotite transformation products. Montmorillonitization of biotite, passing through a stage of mobile chlorite-vermiculites, with an isolation of an independent phase of dioctahedral hydromica (illite) could have begun on the continent and ended as a result of diagenesis. It appears that the clastic material was supplied largely as a result of erosion of pre-Cambrian crystalline rocks, particularly quartzbiotite schists, and granitoids. At the same time sedimentary and metasedimentary rocks were being eroded, which is evidenced by regeneration rim on some rounded quartz grains. Therefore, quartz and trioctahedral micas are "leading" components representing a continental supply. It should be pointed out, however, that a part of biotite might not have a terrigenous origin, but a volcanogenic origin. The latter is associated with the destruction of a series of alkaline rocks ranging from ankaramite to trachybasalts and trachytes rich in phlogopite, and widespread in the northern part of the Jan-Mayen Ridge (Flower, 1969). The Bjurenberg volcano in this part of Jan-Mayen Island has a late Pleistocene age. 
Volcanogenic material is represented by montmorillonite which is present in the sediments clay matrix and less frequently as independent layers.

3 . Series 2 differs drastically from the overlying and from underlying deposits and is composed of siliceousclay sediment. The upper portion contains very little admixture of terrigenous material. The deposition of the Series 2 sediments during the Miocene represents a period of a high pelagic input. The main clay mineral is volcanogenic montmorillonite developed by alteration of the clastic glasses with a middle trachy (?) - andesitedacite- composition. In contrast to typical pelagic Femontmorillonites recovered at Hole 337 , these "middle" montmorillonites are resistant to acid treatment.

4. In the very thick and uniform series embracing Series 3 and 4 , alternating clayey siltstones and clays are present, which have varying ratios of terrigenous to volcanogenic components.

In the upper part of Series 3 (Oligocene-Miocene) there is an interlayer of a peculiar Fe-montmorillonite clay with a Fe-rhodochrosite and $\mathrm{Mn}$-siderite. The development of this rather "exotic" sediment alien to surrounding deposits in its chemical composition, is probably related to the afflux of hydrothermal Fe-Mn solutions.

The interbedding in these two series of subseries having bioturbation textures and enriched in vegetable detritus, seems to indicate stages of intensified "continentality" of the basin.

5 . Series 5 is characterized by a wide-scale development of montmorillonite clays of a bentonite type at the top forming a separate subseries and at the base, the matrix of graywackes. The graywackes are polygenetic. Clastics are represented by a typical association of quartz from metamorphic and sedimentary platform complexes. Identical in nature to the upper Subseries $5_{1}$, the subseries of bentonite-like clays seems to have been formed at the expense of sufficiently intermediate alkaline hyaloclastics (trachyandesites). This is attested to both by chemical and by petrographic composition, which indicates a comparatively slight montmorillonitization. Therefore, after the alkaline basalt volcanism that preceded the accumulation of the sedimentary series, the area of Site 345 throughout the entire Oligocene, Miocene, and Pleistocene (?) was an arena of middle and, in all likelihood, alkaline volcanism.

\section{REFERENCES}

Flower, M.F., 1969. Phlogopites from Jan-Mayen Islands (North Atlantic) Earth Planet. Sci. Lett., v. 6, p. 461-466. Kossovskaya, A.G., Drits, V.A., and Alexandrova, V.A., 1963. On trioctahedral micas in sedimentary rocks: Intern. Clay Conf. Proc., Stockholm (Pergamon Press), p. 147. 169. 